\title{
Analisis Kemampuan Berpikir Kreatif Siswa Memecahkan Masalah HOTS dalam Setting Model Kooperatif Jigsaw
}

\author{
Adellia Devi Windasari ${ }^{1}$, Yus Mochamad Cholily ${ }^{2}$ \\ 1,2 Program Studi Magister Pendidikan Matematika, Universitas Muhammadiyah Malang \\ Jl. Raya Tlogomas No.246, Malang, Indonesia \\ adeliadevi9793@gmail.com ${ }^{1}$
}

\begin{abstract}
Describing students' creative thinking ability solving HOTS problems in a cooperative Jigsaw model setting. This type use a descriptive qualitative approach. Research subjects is 31 students of class X SMA Negeri Angsana. Students' creative thinking data skills were obtained through a HOTS-type essay test. Data analysis firstly checks results of student work use a rubric and concludes the results. Then test measured refers to the new scoring and the results are categorized. The results showed students' creative thinking abilities aspect of originality got a proportion of $70.9 \%$, fluency $59.6 \%$, flexibility $55.64 \%$, and detail $50 \%$. Students' creative thinking skills show that most of them can provide different ways, namely elimination and substitution. There is one student who can solve the problem using two methods and correctly. Most of the students were not careful in making calculations to show the correct process. While the rest of the students are more on the process of calculating that is not completed or not answered. Thus the problem can be that the creative thinking ability of students in solving HOTS in the Jigsaw cooperative arrangement model of 31 students of class X SMA Negeri Angsana is in the creative category with a proportion of $48.38 \%$.
\end{abstract}

Keywords: Creative Thinking Ability, Problem Solving HOTS, Cooperative Jigsaw Model

\begin{abstract}
Abstrak
Mendeskripsikan kemampuan berpikir kreatif siswa memecahkan masalah HOTS dalam setting model kooperatif Jigsaw. Jenis penelitian dengan pendekatan kualitatif deskriptif dengan 31 siswa X SMA Negeri Angsana. Data kemampuan berpikir kreatif siswa melalui tes uraian bertipe HOTS. Analisis data untuk mengetahui kemampuan berpikir kreatif siswa dengan terlebih dahulu mengecek hasil pekerjaan siswa menggunakan rubrik dan menyimpulkan hasilnya. Kemudian penilaian tes mengacu pada pedoman penskoran dan hasilnya dikategorikan. Hasil menunjukkan kemampuan berpikir kreatif untuk aspek orisinalitas mendapat persentase 70,9\%, kelancaran 59,6\%, fleksibilitas 55,64\%, dan kerincian 50\%. Kemampuan berpikir kreatif siswa menunjukkan bahwa sebagian besar sudah dapat memberikan dua cara yang berbeda yaitu eliminasi dan subtitusi. Terdapat satu siswa yang menyelesaikan soal dengan menggunakan dua cara dan sesuai. Sebagian besar siswa kurang teliti dalam melakukan perhitungan meskipun menunjukan proses yang benar. Sedangkan sisanya siswa lebih pada proses perhitungan yang tidak terselesaikan atau tidak menjawab. Kesimpulan menyatakan bahwa kemampuan berpikir kreatif siswa dalam memecahkan masalah HOTS dalam setting model kooperatif Jigsaw dari 31 siswa kelas X SMA Negeri Angsana terdapat pada kategori kreatif dengan persentase $48,38 \%$.
\end{abstract}

Kata Kunci: Kemampuan Berpikir Kreatif, Pemecahan Masalah HOTS, Model Kooperatif Jigsaw

Copyright (c) 2021 Adellia Devi Windasari, Yus Mochamad Cholily

$\triangle$ Corresponding author: Adellia Devi Windasari

Email Address: adeliadevi9793@gmail.com (Jl. Raya Tlogomas No.246, Malang, Indonesia)

Received 11 Januari 2021, Accepted 18 Maret 2021, Published 19 Maret 2021

\section{PENDAHULUAN}

Pembelajaran sekarang ini berorientasi pendidikan pada abad 21 yang mengharuskan siswanya dibekali dengan kompetensi berpikir kreatif, memcahkan masalah, komunikasi, representasi, literasi informasi dan TIK (Binkley et al., 2010). Dalam lampiran Kemendikbud, (2016) disebutkan bahwa pembelajaran disekolah seharusnya dapatberupa pembelajaran yang interaktif, inspiratif, menyenangkan, memotivasi, memberi ruang untuk kreativitas, kemandirian sesuai bakat dan minat siswa. Demikian dapat disimpulkan bahwa kreativitas merupakan kompetensi penting penyelengaraan 
pendidikan dan pembelajaran dikelas. Dari pemaparan diatas aspek penting yang akan dibahas pada penelitian ini merupakan kemampuan berpikir kreatif.

Kemampuan berpikir kreatif adalah kemampuan berpikir tingkat tinggi yang merangsang munculnya ide baru oleh masalah non rutin (Puspitasari et al., 2018). Berpikir kreatif juga merupakan kemampuan seseorang untuk menyelesaikan suatu permasalahan dari berbagai macam solusi (Armitage, Pihl, \& Ryberg, 2018; Qadri, Ikhsan, \& Yusrizal, 2019). Sedangkan menurut Naimnule, Kartono, \& Asikin, (2020) kemampuan berpikir kreatif adalah keahlian dalam memecahkan soal kompleks dan rumit. Aspek didalam kemampuan berpikir kreatif yaitu orisinalitas, kelancaran, fleksibilitas dan kerincian (Nehe et al., 2017). Akan tetapi survey empat tahunan TIMMS tahun 2015 yang diselenggarakan oleh IEA menyatakan jika bidang matematika siswa rendah.

Masalah non rutin dapat diberikan saat melatih proses berpikir kreatif siswa, salah satunya merupakan soal bertipe HOTS. Tipe soal ini mengandung kemampuan memecahkan masalah, berpikir kreatif, berpikir kritis dan pengambilan keputusan (Dinni, 2018). Dalam pemecahan masalah menurut polya terdapat beberapa langkah utama yaitu memahami masalah, menyusun rencana pemecahan masalah, melaksanakan rencana dan verifikasi atau melihat kembali hasil pemecahan masalah (Abdullah dkk., 2017; Suryono, 2019; Sunendar, 2017). Indikator langkah - langkah polya yaitu mengidentifikasi aspek yang diketahui, menulis pertanyaan dari permasalahan, menghubungkan masalah, menyusun rencana, proses pemecahan masalah dan yang terakhir untuk mengecek ketepatan suatu jawaban dari pemecahan masalah (Nurkaeti, 2018).

Saat ini negara Indonesia menggunakan kurikulum 2013 yang berorientasi untuk mengembangkan kemampuan berpikir HOTS disekolah. Kemampuan berpikir terbagi menjadi dua yaitu Low Order Thinking (LOT) dan High Order Thinking (HOT) (Tanujaya et al., 2017). Taksonomi bloom revisi dari Anderson dan Krathwohl bahwa proses kognitif terbagi dua yaitu LOT didalamnya ada aspek hafal, paham dan terapkan, kemudian yang kedua merupakan HOT mencakup aspek analisis, evaluasi dan cipta (Krathwohl, 2001). Peningkatan kemampuan berpikir kreatif terlaksana ketika berlangsungnya pembelajaran didalam kelas (Yusnaeni et al., 2017).

Kurikulum 2013 di Indonesia pelaksanaan proses pembelajaran berpusat pada siswa. Pembelajaran kooperatif sesuai dan didalamnya terdapat model kooperatif Jigsaw. Guru sebagai pelaksana pembelajaran dapat menggunakan Jigsaw agar kemampuan siswa berkembang. Nurmalia, Halim, \& Syahrun, (2020) menyatakan bahwa model kooperatif jigsaw merupakan model untuk melatih siswa bertanggung jawab kepada kelompok kecil atas materi yang diberikan kepada teman satu kelompok (Abed et al., 2019).

Penelitian sebelumnya membahas tentang perbandingan model kooperatif Jigsaw berbantuan kartu soal dan model konvensional untuk meningkatkan kemampuan berpikir kreatif siswa (Diani, 2020). Penelitian lainnya menjelaskan bahwa model kooperatif Jigsaw dapat meningkatkan kemampuan berpikir kreatif siswa (Nurmalia, Halim, \& Syahrun, 2020; Sumarni et al., 2018 ; Purba \& Sinaga, 2020). 
Analisis Kemampuan Berpikir Kreatif Siswa Memecahkan Masalah HOTS dalam Setting Model Kooperatif Jigsaw,

Penelitian lain juga menyebutan bahwa kemampuan metakognitif dan kemampuan berpikir kreatif terlaksana dari penerapan model kooperatif Jigsaw (Perangin et al., 2020).

Kemampuan berpikir kreatif dilatih dengan mengerjakan soal non rutin seperti soal tipe HOTS. Penelitian sebelumnya membahas bahwa pemberian soal HOTS dapat melihat tingkat kemampuan berpikir kreatif siswa (Zaiyar \& Rusmar, 2020), level berpikir kreatif siswa berdasarkan kemampuan visual spasial dalam materi geometri (Aini dkk., 2020).

Berdasarkan hasil deskripsi diatas dapat diketahui bahwa penerapan model pembelajaran kooperative jigsaw dapat meningkatkan kemampuan berpikir kreatif siswa. Kemampuan berpikir kreatif dapat menggunakan soal tipe HOTS. Penelitian ini ingin melihat bagaimana kemampuan berpikir kreatif siswa dalam memecahkan masalah HOTS dalam setting model pembelajaran kooperatif Jigsaw. Oleh sebab itu penelitian ini fokus untuk mendeskripsikan kemampuan berpikir kreatif dalam memecahkan masalah HOTS dalam setting model pembelajaran kooperatif Jigsaw.

\section{METODE}

Jenis penelitian ini adalah pendekatan kualitatif deskriptif. Subjek penelitian adalah siswa berjumlah 31 kelas X SMA Negeri Angsana yang memperoleh model pembelajaran kooperatif Jigsaw. Penelitian ini berlangsung dalam dua kali pertemuan tanggal 12 dan 19 November 2020 dengan salah satu guru matematika sebagai pelaksana. Tahap penelitian ini ada tiga yaitu tahap persiapan yaitu pembuatan instrumen penelitian yaitu RPP yang sudah divalidasi terlebih dahulu dan soal tipe HOTS yang di adopsi dari soal UN. Berikut merupakan soal HOTS untuk melihat kemampuan berpikir kreatif siswa yang diadopsi dari soal UN SMA tahun 2019 materi SPLTV:

\section{Jumlah tiga bilangan adalah 60 . Bilangan pertama enam lebihnya dari jumlah dua bilangan lain. Bilangan kedua sama dengan $\frac{1}{2}$ dari jumlah dua bilangan lain. Tentukan bilangan pertama, kedua dan ketiga tersebut ...}

\section{Gambar 1. Soal HOTS materi SPLTV}

Tahap kedua adalah pelaksanaan penelitian yang diselengarakan dengan mengacu pada RPP untuk model pembelajaran kooperatif Jigsaw oleh salah satu guru matematika disekolah tersebut. Tahap ketiga merupakan tahap pengolahan data dari hasil pekerjaan siswa dalam memecahkan masalah HOTS. Berikut adalah tabel indikator kemampuan berpikir kreatif siswa dalam memecahkan masalah mengadopsi dari Abdullah dkk., (2017) dan Lin \& Wu, (2016):

Tabel 1. Indikator kemampuan berpikir kreatif dalam memecahkan masalah

\begin{tabular}{|c|l|}
\hline Aspek & \multicolumn{1}{c|}{ Indikator } \\
\hline Orisinalitas & $\begin{array}{l}\text { Siswa mampu menuliskan yang diketahui dan ditanya dalam memberikan } \\
\text { jawaban dengan cara berbeda. }\end{array}$ \\
\hline Kelancaran & $\begin{array}{l}\text { Siswa mampu menggunakan metode yang dipilih untuk menghasilkan beberapa } \\
\text { jawaban. }\end{array}$ \\
\hline Fleksibilitas & $\begin{array}{l}\text { Siswa mampu menyajikan hasil hitungan dengan metode yang dipilih dari } \\
\text { sudut pandang yang berbeda. }\end{array}$ \\
\hline Kerincian & Siswa menguraikan hasil jawaban dan mampu merinci jawaban secara detail. \\
\hline
\end{tabular}


Analisis data untuk mengetahui kemampuan berpikir kreatif siswa dilakukan dengan melihat hasil pekerjaan siswa yang dikoreksi menggunakan rubrik kemampuan berpikir kreatif siswa:

Tabel 2. Rubrik Pedoman Penskoran Tes Kemampuan Berpikir Kreatif

\begin{tabular}{|c|c|c|c|}
\hline No. & Aspek & Skor & Respon siswa \\
\hline \multirow[t]{5}{*}{1} & \multirow{5}{*}{ Orisinalitas } & 0 & Tidak menjawab atau memberi jawaban yang salah. \\
\hline & & 1 & $\begin{array}{l}\text { Memberi jawaban dengan caranya sendiri tetapi tidak dapat } \\
\text { dipahami. }\end{array}$ \\
\hline & & 2 & $\begin{array}{l}\text { Memberi jawaban dengan cara sendiri, proses hitungan sudah } \\
\text { terarah tetapi tidak selesai. }\end{array}$ \\
\hline & & 3 & $\begin{array}{l}\text { Memberi jawaban dengan cara sendiri tetapi terdapat kekeliruan } \\
\text { dalam hitung sehingga hasilnya salah. }\end{array}$ \\
\hline & & 4 & $\begin{array}{l}\text { Memberi jawabn dengan caranya sendiri dan proses hitung dan } \\
\text { hasil benar. }\end{array}$ \\
\hline \multirow[t]{5}{*}{2} & \multirow[t]{5}{*}{ Kelancaran } & 0 & $\begin{array}{l}\text { Tidak menjawab atau memberi ide jawaban yang tidak relevan } \\
\text { dengan masalah. }\end{array}$ \\
\hline & & 1 & Memberi ide jawaban relevan dan jawaban salah. \\
\hline & & 2 & Memberi ide jawaban relevan dan jawaban benar. \\
\hline & & 3 & Memberi lebih dari satu ide relevan dan jawaban salah. \\
\hline & & 4 & Memberi lebih dari satu ide relevan dan jawaban benar. \\
\hline \multirow[t]{5}{*}{3} & \multirow[t]{5}{*}{ Fleksibilitas } & 0 & $\begin{array}{l}\text { Tidak menjawab atau memberi jawaban satu cara atau lebih tapi } \\
\text { semua salah. }\end{array}$ \\
\hline & & 1 & memberi jawaban dengan satu cara tapi memberi jawaban salah. \\
\hline & & 2 & Memberi jawaban dengan satu cara, tapi hitung dan hasil benar. \\
\hline & & 3 & $\begin{array}{l}\text { Memberi jawaban lebih dari satu cara tapi hasil ada yang salah } \\
\text { karena kekeliruan dalam proses hitung. }\end{array}$ \\
\hline & & 4 & $\begin{array}{l}\text { Memberi jawaban lebih dari satu cara, proses hitung dan hasil } \\
\text { benar. }\end{array}$ \\
\hline \multirow[t]{5}{*}{4} & \multirow[t]{5}{*}{ Kerincian } & 0 & Tidak menjawab atau memberi jawaban salah. \\
\hline & & 1 & Terdapat kesalahan menjawab dan tidak ada rincian. \\
\hline & & 2 & Terdapat kesalahan menjawab dan ada rincian. \\
\hline & & 3 & Terdapat kesalahan jawaban dan ada kerincian yang rinci. \\
\hline & & 4 & Memberi jawaban benar dan rinci. \\
\hline
\end{tabular}

Sumber: (Zaiyar \& Rusmar, 2020)

Kemudian perolehan skor dipersentasekan dan dikategorikan seperti tabel dibawah ini:

Tabel 3. Kategori Kemampuan Berpikir Kreatif Siswa

\begin{tabular}{|c|c|}
\hline Nilai & Kategori \\
\hline $85<$ Skor $\leq 100$ & Sangat Kreatif \\
\hline $71<$ Skor $\leq 85$ & Kreatif \\
\hline $56<$ Skor $\leq 71$ & Cukup Kreatif \\
\hline $41<$ Skor $\leq 56$ & Kurang Kreatif \\
\hline$<40$ & Sangat Kurang Kreatif \\
\hline
\end{tabular}

Sumber: (Rupalestari \& Prabawanto, 2020)

\section{HASIL DAN DISKUSI}

Penelitian ini dilakukan untuk mendeskripsikan kemampuan berpikir kreatif dalam memecahkan masalah HOTS dalam setting model kooperatif Jigsaw. Berdasarkan hasil pemecahan masalah HOTS siswa 
Analisis Kemampuan Berpikir Kreatif Siswa Memecahkan Masalah HOTS dalam Setting Model Kooperatif Jigsaw,

berdasarkan indikator dan rubrik penskoran kemampuan berpikir kreatif siswa dalam memecahkan masalah siswa didapatkan hasil seperti pada tabel berikut:

Tabel 4. Kategori Kemampuan Berpikir Kreatif Siswa

\begin{tabular}{|c|c|c|c|}
\hline Nilai & Kategori & $\begin{array}{c}\text { Jumlah } \\
\text { Siswa }\end{array}$ & Persentase (\%) \\
\hline $85<$ Skor $\leq 100$ & Sangat Kreatif & 2 & $6,45 \%$ \\
\hline $71<$ Skor $\leq 85$ & Kreatif & 15 & $48,38 \%$ \\
\hline $56<$ Skor $\leq 71$ & Cukup Kreatif & 4 & $12,90 \%$ \\
\hline $41<$ Skor $\leq 56$ & Kurang Kreatif & 3 & 9,67 \\
\hline$<40$ & Sangat Kurang Kreatif & 7 & 22,57 \\
\hline \multicolumn{2}{|c|}{ Total } & 31 & $100 \%$ \\
\hline
\end{tabular}

Dari tabel 4 diatas dapat dilihat bahwa persentase terbesar adalah kategori kreatif dengan besar persentase sebesar 48,38\%. Kemudian berikut adalah tabel persentase kemunculan indikator kemampuan berpikir kreatif dari hasil jawaban siswa:

Tabel 5. Persentase kemunculan indikator kemampuan berpikir kreatif

\begin{tabular}{|c|c|}
\hline Indikator & Persentase Kemunculan \\
\hline Orisinalitas & $70,9 \%$ \\
\hline Kelancaran & $59,6 \%$ \\
\hline Fleksibilitas & 55,64 \\
\hline Kerincian & $50 \%$ \\
\hline
\end{tabular}

Dari tabel dihasilkan bahwa indikator kemampuan berpikir kreatif siswa dengan kemunculan persentase tertinggi adalah indikator orisinalitas dengan besar persentase $70,9 \%$. Sementara indikator terendah adalah kerincian yang memperoleh persentase sebesar 50\%. Penelitian ini juga menunjukkan bahwa siswa sebagian besar sudah dapat memberikan dua cara yang berbeda dalam mengerjakan soal yaitu eliminasi dan subtitusi. Terdapat satu siswa yang dapat menyelesaikan soal dengan menggunakan dua cara tersebut dan benar. Sebagian besar siswa kurang teliti dan cermat dalam melakukan perhitungan meskipun menunjukan proses yang benar. Sedangkan sisanya siswa lebih pada proses perhitungan yang tidak terselesaikan atau tidak menjawab.

Berdasarkan hasil analisis data didapatkan hasil kemampuan berpikir kreatif 31 siswa kelas X SMA Negeri Angsana dalam memecahkan masalah HOTS setting model kooperatif Jigsaw dalam kategori kreatif. Hal tersebut seperti pada penelitian yang pernah dilakukan oleh Diani, (2020) dan Nurmalia, Halim, \& Syahrun, (2020). Hal itu karena model kooperatif Jigsaw membuat siswa lebih kreatif dalam mengutarakan ide dengan sesama teman dalam kelompok (Abed et al., 2019; (Purba \& Sinaga, 2020; Benedine, 2020).

Tahap model kooperatif Jigsaw dapat menjadi faktor untuk meningkatkan kemampuan berpikir kreatif. Tahap diawali dengan membagi siswa kedalam $4-6$ kelompok dimana setiap kelompok mendapat satu topik bahasan. Setiap kelompok yang sudah mempunyai bahasan menyebar ke dalam kelompok lain dan mempresentasikan hasil diskusi. Setelah selesai langkah terakhir adalah kembali 
kekelompok awal untuk mendiskusikan hasil yang didapat. Sehingga kreativitas siswa dalam mengolah data dikelompok awal hingga mempresentasikan hasil diskusi kelompok dapat melatih kreativitas siswa.

Pemecahan masalah HOTS yang diberikan dapat melihat tingkat kemampuan berpikir kreatif siswa. Hal ini sesuai penelitian dari Aini et al., (2020) dan Zaiyar \& Rusmar, (2020). Hal ini dikarenakan pemberian masalah HOTS dapat meningkatkan kemampuan berpikir kreatif (Anggraini et al., 2019). Penelitian ini mencoba melihat dan mendeskripsikan kemampuan berpikir kreatif dalam menyelesaikan masalah HOTS setting Jigsaw dan mendapat hasil pada kategori kreatif.

Secara umum penerapan model Jigsaw berjalan sesuai keinginan. Tetapi terdapat juga beberapa kendala dalam menyelesaikan penelitian. Secara umum siswa dalam pemberian bahasan materi SPLTV masih perlu banyak bantuan dari guru sehingga secara otomatis menuntun siswa untuk menghasilkan jawaban. Kendala lainnya adalah penerapan model kooperatif Jigsaw sendiri yang masih membuat siswa sedikit bingung untuk memulai suatu pembelajaran sehingga diperlukan waktu sedikit lebih banyak untuk mengatur jalannya pembelajaran. Kendala lain lagi adalah kesulitan siswa dalam memecahkan soal HOTS dengan waktu yang diberikan oleh guru pada pertemuan terakhir. Kendala kendala dalam penelitian ini dapat menjadi bahan sebagai saran bagi peneliti selanjutnya agar dapat dengan maksimal menerapkannya.

\section{KESIMPULAN}

Hasil kemampuan berpikir kreatif siswa dari 31 siswa kelas X SMA Negeri Angsana yang terlibat dalam penelitian untuk mengukur tingkat kemampuan berpikir kreatif terdapat pada kategori kreatif dengan persentase 48,38\%. Kemudian untuk aspek orisinalitas mendapat persentase sebesar 70,9\%, kelancaran 59,6\%, fleksibilitas 55,64\%, dan kerincian 50\%. Hasil penelitian menunjukkan bahwa siswa sebagian besar sudah dapat memberikan dua cara yang berbeda dalam mengerjakan soal yaitu eliminasi dan subtitusi. Terdapat satu siswa yang dapat menyelesaikan soal dengan menggunakan dua cara tersebut dan benar. Sebagian besar siswa kurang teliti dalam melakukan perhitungan meskipun menunjukan proses yang benar. Sedangkan sisanya siswa lebih pada proses perhitungan yang tidak terselesaikan atau tidak menjawab.

\section{UCAPAN TERIMA KASIH}

Peneliti mengucapkan syukur kepada Allah SWT karena telah memberikan kelancaran dalam proses penulisan artikel ini. Kemudian berterima kasih juga kepada kedua orang tua saya yang tidak henti memberi dukungan. Terima kasih juga pada Prof. Dr. Yus Mochamad Cholily sebagai pembimbing dan mengarahkan dalam menyelesaikan artikel ini. 
Analisis Kemampuan Berpikir Kreatif Siswa Memecahkan Masalah HOTS dalam Setting Model Kooperatif Jigsaw,

Adellia Devi Windasari, Yus Mochamad Cholily

\section{DAFTAR PUSTAKA}

Abdullah, A. H., Mokhtar, M., Halim, N. D. A., Ali, D. F., Tahir, L. M., \& Kohar, U. H. A. (2017). Mathematics teachers' level of knowledge and practice on the implementation of higher-order thinking skills (HOTS). Eurasia Journal of Mathematics, Science and Technology Education, 13(1), 3-17. https://doi.org/10.12973/eurasia.2017.00601a

Abed, A. Z., Sameer, S. A., Kasim, M. A., \& Othman, A. T. (2019). Predicting Effect Implementing the Jigsaw Strategy on the Academic Achievement of Students in Mathematics Classes. International Electronic Journal of Mathematics Education, 15(1), 1-7. https://doi.org/10.29333/iejme/5940

Aini, A. N., Mukhlis, M., Annizar, A. M., Jakaria, M. H. D., \& Septiadi, D. D. (2020). Creative thinking level of visual-spatial students on geometry HOTS problems. Journal of Physics: Conference Series, 1465(1). https://doi.org/10.1088/1742-6596/1465/1/012054

Anggraini, N. P., Budiyono, \& Pratiwi, H. (2019). Analysis of higher order thinking skills students at junior high school in Surakarta. Journal of Physics: Conference Series, 1211(1). https://doi.org/10.1088/1742-6596/1211/1/012077

Armitage, A., Pihl, O., \& Ryberg, T. (2018). PBL and Creative Processes. June 2015. https://doi.org/10.5278/ojs.jpblhe.v3i1.1199

Binkley, M., Erstad, O., Herman, J., Raizen, S., \& Ripley, M. (2010). Defining 21st century skills. January.

Diani, A. H. (2020). Mathematical Creative Thinking Ability Observed from Student Learning Motivation in Jigsaw Cooperative Learning Assisted by Problem Cards. 9(1), 66-73. https://doi.org/10.15294/ujme.v9i1.38102

Dinni, H. N. (2018). HOTS ( High Order Thinking Skills ) dan Kaitannya dengan Kemampuan Literasi Matematika. Prisma, 1, 170-176.

Kemendikbud. (2016). Lampiran Peraturan Menteri Pendidikan dan Kebudayaan Nomor 22 Tahun 2016. 23(45), 5-24.

Krathwohl, D. R. (2001). A taxonomy for learning, teaching, and assessing: a revision of Bloom's $\begin{array}{lllll}\text { taxonomy of educational } & \text { objectives. } & 41(4), & 352 .\end{array}$ http://books.google.com/books?id=JPkXAQAAMAAJ\&pgis=1

Lin, C. S., \& Wu, R. Y. W. (2016). Effects of Web-Based creative thinking teaching on students' creativity and learning outcome. Eurasia Journal of Mathematics, Science and Technology Education, 12(6), 1675-1684. https://doi.org/10.12973/eurasia.2016.1558a 
Naimnule, M., Kartono, \& Asikin, M. (2020). Mathematics Problem Solving Ability in Terms of Adversity Quotient in Problem Based Learning Model With Peer Feedback. Unnes Journal of Mathematics Education Research, 10(2), 222-228. http://journal.unnes.ac.id/sju/index.php/ujmer

Nehe, M., Surya, E., \& Syahputra, E. (2017). Creative Thinking ability to Solving Equation and Nonequation of Linear Single Variable in VII Grade Junior High School. Ijariie, 3(1), 2146-2152.

Nurkaeti, N. (2018). Polya'S Strategy: an Analysis of Mathematical Problem Solving Difficulty in 5Th Grade Elementary School. EduHumaniora | Jurnal Pendidikan Dasar Kampus Cibiru, 10(2), 140. https://doi.org/10.17509/eh.v10i2.10868

Nurmalia, Halim, A., \& Syahrun, N. (2020a). Application of jigsaw type cooperative learning to improve student creative thinking skills. Journal of Physics: Conference Series, 1460(1). https://doi.org/10.1088/1742-6596/1460/1/012142

Nurmalia, Halim, A., \& Syahrun, N. (2020b). Application of jigsaw type cooperative learning to improve student creative thinking skills. Journal of Physics: Conference Series, 1460(1). https://doi.org/10.1088/1742-6596/1460/1/012142

Perangin angin, R. N., Sinaga, B., \& Syahputra, E. (2020). Qualitative Analysis of Metacognition Ability and Creativity Thinking with Jigsaw Cooperative Learning Model. Advances in Social Science, Education and Humanities Research, 384(Aisteel), 224-229. https://doi.org/10.2991/aisteel-19.2019.48

Puspitasari, L., In'am, A., \& Syaifuddin, M. (2018). Analysis of Students' Creative Thinking in Solving Arithmetic Problems. International Electronic Journal of Mathematics Education, 14(1), 49-60. https://doi.org/10.12973/iejme/3962

Qadri, L., Ikhsan, M., \& Yusrizal, Y. (2019). Mathematical Creative Thinking Ability for Students Through REACT Strategies. International Journal for Educational and Vocational Studies, 1(1), 58. https://doi.org/10.29103/ijevs.v1i1.1483

Rupalestari, D., \& Prabawanto, S. (2020). Students' creative thinking skill and its influential factors in quadrilateral topic viewed by students' cognitive. Journal of Physics: Conference Series, 1521(3). https://doi.org/10.1088/1742-6596/1521/3/032054

Sunendar, A. (2017). Pembelajaran Matematika dengan Pemecahan Masalah. Theorems ( the Original Research of Mathematic ), 2(1), 86-93.

Suryono, F. B., Pascasarjana, D. P., \& Malang, U. M. (2019). Kemampuan komunikasi matematis siswa smp sunan kalijogo jabung dalam pemecahan masalah berdasarkan level van hiele. November.

Tanujaya, B., Mumu, J., \& Margono, G. (2017). The Relationship between Higher Order Thinking Skills and Academic Performance of Student in Mathematics Instruction. International Education 
Analisis Kemampuan Berpikir Kreatif Siswa Memecahkan Masalah HOTS dalam Setting Model Kooperatif Jigsaw,

Adellia Devi Windasari, Yus Mochamad Cholily

Studies, 10(11), 78. https://doi.org/10.5539/ies.v10n11p78

Yusnaeni, Y., Corebima, A. D., Susilo, H., \& Zubaidah, S. (2017). Creative thinking of low academic student undergoing search solve create and share learning integrated with metacognitive strategy. International Journal of Instruction, 10(2), 245-262. https://doi.org/10.12973/iji.2017.10216a

Zaiyar, M., \& Rusmar, I. (2020). Students ' Creative Thinking Skill in Solving Higher Order Thinking Skills ( HOTS ) Problems. Al-Jabar: Jurnal Pendidikan Matematika, 11(1), 111-120. 